\title{
JOURNAL.RU
}

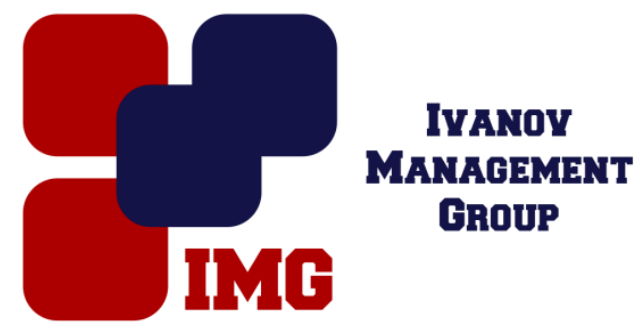

Егоренкова О.С.

Государственное бюджетное общеобразовательное учреждение г. Москвы «Специальная (коррекционная) школа № 1708» Москва, Россия

doi: $10.18411 / 1 \mathrm{j}-31-07-2017-08$

idsp 000001:1j-31-07-2017-08

\section{«Формирование игровой деятельности в раннем возрасте как средства развития эмоционально-волевой сферы детей с нарушениями речи»}

\section{Аннотация}

Данная статья посвящена проблеме развития эмоционально-волевой сферы детей раннего возраста имеющих нарушения речевого развития.

Ключевые слова: воля, настроение, опосредованное поведение, ранний возраст, самоконтроль, саморегуляция, самосознание, чувства, целенаправленность, целеполагание, эмоции, эмоциональное заражение, эмоциональная отзывчивость, эмпатия.

Актуальность проблемы развития эмоционально-волевой сферы в раннем возрасте очевидна, потому что эмоции и воля тесно связаны с познавательными способностями и речью. По мнению Е.Н. Винарской, предпосылки речевого неблагополучия детей в значительной степени связаны с неблагополучием их эмоциональной сферы [2,c.34]. Задержка речевого и интеллектуального развития, в свою очередь, накладывает отпечаток на эмоционально-волевую сферу. Подчеркивая значимость эмоционального развития в раннем возрасте, В.В. Лебединский говорит о том, что «память создает условия для сохранения следов эмоциональных переживаний. Речь обозначает, дифференцирует и обобщает эмоциональные переживания» [7,с.7].

В раннем возрасте выражение эмоций и поведенческие реакции ребенка еще спонтанны и ситуативны, он не может их контролировать и сдерживать. На неисполнение желаний или не успешность в действиях реагирует криком и 
плачем. Малыш не умеет адекватно воспринимать настроение и чувства окружающих. Результаты же диагностического обследования эмоциональноволевой сферы детей раннего возраста с нарушениями развития речи помогли выявить ряд проблем:

- характерно преобладание аффективного эмоционального фона, дети не способны адекватно реагировать на эмоционально окрашенные и оценочные высказывания;

- дети не умеют контролировать свои действия и не хотят преодолевать трудности, что приводит к снижению игровой активности.

Это свидетельствует о необходимости проведения целенаправленной и систематической работы по развитию и коррекции эмоционально-волевой сферы детей данной категории в условиях образовательной организации.

Одним из средств развития и коррекции эмоционально-волевой сферы детей раннего возраста является игра, так как она всегда эмоционально насыщенна, создает зону ближайшего развития и является ведущей деятельностью.

Задачи развития эмоционально-волевой сферы детей раннего возраста в условиях образовательной организации:

Коррекционные:

- Обогащение и разнообразие эмоционального опыта;

- Осознание своих движений и действий;

- Повышение игровой и коммуникативной активности.

- Развивающие:

- Формирование эмоциональной отзывчивости;

- Развитие саморегуляции и самоконтроля эмоций и поведения.

- Обучающие:

- Обучение приемлемым способам выражения эмоциональных переживаний;

- Обучение умению планировать свои действия и контролировать их выполнение.

- Психотерапевтические:

- Создание условий психологического комфорта;

- Повышение эмоционального тонуса. 
На сегодняшний день существуют программы по развитию и коррекции эмоционально-волевой сферы и программы по развитию игровой деятельности. Мною был обобщен, систематизирован и адаптирован материал для работы с детьми раннего возраста в условиях образовательной организации.

Таблицуа 1.

Закономерности развития действий с игровым материалом в раннем возрасте

\begin{tabular}{|c|c|c|}
\hline $\begin{array}{c}\text { Этапы развития действий с } \\
\text { игровым материалом }\end{array}$ & Возраст & Содержание деятельности \\
\hline $\begin{array}{c}\text { Неспецифические } \\
\text { манипуляции }\end{array}$ & $\begin{array}{l}\mathrm{N}-5-9 \\
\text { месяцев }\end{array}$ & $\begin{array}{c}\text { Стереотипные действия со всеми игрушками: } \\
\text { постукивание, размахивание, перекладывание из одной } \\
\text { руки в другую, сосание, бросание. }\end{array}$ \\
\hline Специфические манипуляции & $\begin{array}{l}\mathrm{N}-9-12 \\
\text { месяцев }\end{array}$ & $\begin{array}{c}\text { Учет физических свойств предмета: сжимание и } \\
\text { разжимание пищащей игрушки, размахивание и } \\
\text { потряхивания погремушкой, отталкивание подвешенных } \\
\text { игрушек. }\end{array}$ \\
\hline Предметные действия & $\mathrm{N}-\mathrm{c} 1$ года & $\begin{array}{c}\text { Использование предмета по их функциональному } \\
\text { назначению: двигает машину взад и вперед, нанизывает } \\
\text { кольца на стержень. } \\
\end{array}$ \\
\hline Процессуальные действия & $\begin{array}{c}\mathrm{N} \text { - с } 1 \text { года } 6 \\
\text { месяцев }\end{array}$ & $\begin{array}{c}\text { Многократное осуществление предметно-игровых } \\
\text { действий, не направленных на более отдаленный или } \\
\text { конечный результат, ребенок получает удовольствие от } \\
\text { самого процесса. }\end{array}$ \\
\hline Игра с элементами сюжета & $\begin{array}{c}\mathrm{N} \text { - с } 2 \text { лет } 6 \\
\text { месяцев }\end{array}$ & $\begin{array}{c}\text { Цепочка логически связанных, целенаправленных, } \\
\text { осмысленных действий. }\end{array}$ \\
\hline
\end{tabular}

Развитие деятельности с игровым материалом у большинства детей поступающих в образовательную организацию находится на стадии формирования собственно предметных действий. На этом этапе роль педагога и его эмоциональная экспрессия велика. В ходе совместной игры ребенок улавливает эмоции взрослого, вследствие чего происходит эмоциональное зарождение, проявляются адекватные ответные эмоциональные реакции. Дальнейшее развитие эмоций происходит в процессе овладения новыми игровыми действиями, которые на этом этапе обязательно должны приводить к ожидаемому результату, что ведет к обогащению эмоционального репертуара и становится источником высокой игровой активности ребенка. Совершая собственно предметные действия с различными игрушками, ребенок начинает их осознавать, что позволяет ему учиться управлять своими движениями. В развитии волевого действия на этом этапе происходит становление целеполагания (однако цель еще задается извне привлекательным предметом) и начинает формироваться целенаправленность в поведении: но пока как подчинение требованиям взрослого.

Далее, ребенок переходит на следующий этап развития игровой деятельности - процессуальных действий. Многократно воспроизводя процессуальную сторону игры, происходит закрепление положительных и 
отрицательных эмоциональных реакций. В процессе игрового действия ребенок начинает осознавать, что вызывает у него положительные эмоции (если все получается), а что - отрицательные (если не получается или реакция взрослого и партнеров по игре была нежелательной). В соответствии с этим ребенок вынужден корректировать свои действия, что ведет к развитию самосознания эмоций. На этом этапе очень важно создавать ситуации, которые дают возможность преодолевать затруднения в осуществлении игровых действий. Положительный опыт преодоления закрепляет положительные эмоции, обладающие мощным развивающим потенциалом. Под влиянием факторов микрогрупповой организации игры, у детей впервые появляются собственные попытки преодоления ситуативной зависимости в поведении и деятельности (попытки сдерживать свои желания), но пока только под контролем взрослого.

Следующий этап «Игра с элементами сюжета». Играя в сюжетноотобразительные игры на бытовые темы, у детей формируется собственное эмоциональное отношения к игровому действию и к игровому сюжету. Сюжетная игра с куклой и другими одушевленными персонажами учит сопереживать грусть и радость, без чего невозможно в будущем развитие эмпатии. Помощь педагога в эмоциональном обыгрывании ситуации, речевые высказывания в ходе игры помогают ребенку распознавать и воспроизводить вербальные и визуальные признаки эмоций. Появление игровой мотивации в сюжетно-отобразительной игре приводит к необходимости планировать результат своего действия. Подгрупповая работа побуждает к формированию самоконтроля действий и желаний, вследствие чего поведение ребенка становится опосредованным: управляется вначале инструкцией педагога, а затем - собственными внутренними инструкциями.

Учитывая непроизвольность внимания детей этого возраста, способность сосредоточиться только на том, что привлекает своим внешним видом, новизной, возможностью манипулировать, необходимо использовать неординарную наглядность в сочетании с яркой эмоциональностью игрового материала. 


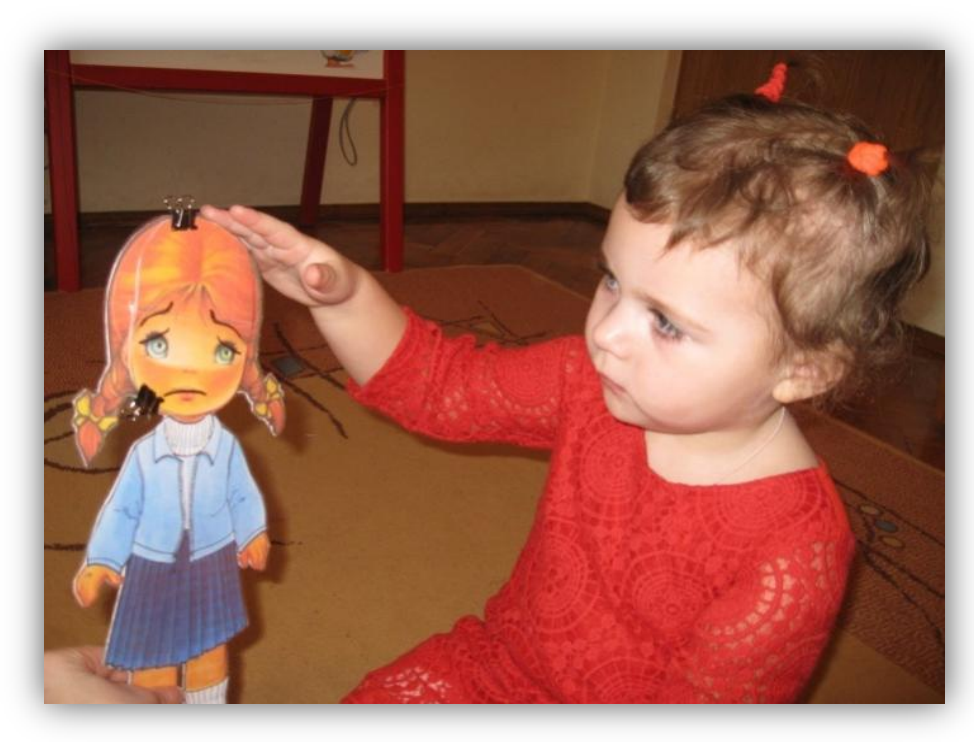

Рисунок 1. Работа с дидактической куклой

Таким образом, в процессе становления основных компонентов игры происходит развитие эмоционально-волевой сферы. Поэтому обучение игровой деятельности в раннем возрасте является важным фактором социального, познавательного и речевого развития.

1. Баряева Л.Б., Гаврилушкина О.П., Зарин А.П., Соколова Н.Д. Программа воспитания и обучения дошкольников с интеллектуальной недостаточностью.- СПб.: «Союз», 2003.

2. Винарская Е.Н. Ранее речевое развитие ребенка и проблемы дефектологии: Периодика раннего развития. Эмоциональные предпосылки освоения языка. - М.: Просвещение, 1987.

3. Дефектология. Словарь-справочник / под ред. Б. П. Пузанова// - М.: Педагогика, 1996.

4. Екжанова Е.А., Стребелева Е.А. Коррекционно - развивающее обучение и воспитание. Программа дошкольных образовательных учреждений компенсирующего вида для детей с нарушением интеллекта. - М: Просвещение, 2012.

5. Лебединский В.В. Никольская О.С., Баенская Е.Р., Либлинг М.М. Эмоциональные нарушения в детском возрасте и их коррекция. - М.: Московский университет. 1990.

6. Обучение сюжетно-ролевой игре дошкольников с проблемами в интеллектуальном развитии: Учеб.-метод. пособие / Под ред. Л.Б. Баряевой, А.П. Зарин, Н.Д. Соколовой. СПб: ЛОИУУ, 1996. .

7. Примерная парциальная образовательная программа для детей раннего возраста (1-3 года) «Первые шаги» / Под.ред. Е.О.Смирновой. - М.:МГППУ, 2014.

8. Современный психологический словарь / сост. и общ. ред. Б.Г. Мещерякова, В.П. Зинченко. - М.:АСТ, 2014г. 